УДК 37(091)(477.8)(092)

DOI:

Дзвенислава Василик, старший викладач кафедри методики музичного виховання і диригування Інституту музичного мистецтва Дрогобицького державного педагогічного університету імені Івана Франка

\title{
ПЕДАГОГІЧНА ДІЯЛЬНІСТЬ АНТІНА КНЯЖИНСЬКОГО
}

У статті подано коротку історію життя і творчості західноукрайнського педагога, науковия, письменника, етнопсихолога, мовознавия, фольклориста Антіна Петровича Княжинського.

Професор Антін Княжинський - людина обширних зачікавлень, великої працездатності та незламноі сили духу. Поклавши своє життя на вівтар служіння рідному народові, він намагався всі свої сили спрямовувати на розвиток української освіти, культури і науки.

Ключові слова: Антін Княжинський; педагогіка; психологія; Самбірська гімназія; "Бойківщчина".

Jim. 11.

Dzvenyslava Vasylyk, Senior Lecturer of the Methodology of Music Education and Conducting Department Institute of Musical Art Drohobych Ivan Franko State Pedagogical University

\section{PEDAGOGICALACTIVITY OF ANTIN KNYAZHYNSKIY}

The beginning of the twentieth century for the culture of Galicia was particularly rich: in opposition to political and economic problems, Ukrainian pedagogy, musicology, folklore, linguistics, and literature were developing. Already from the 90 s of the twentieth century, Ukrainians were able to legally process materials from the pre-Soviet period, publish information about the leaders of Ukrainian culture and science banned by the Soviet authorities, and study their creative achievements. To the little-known, unfortunately, names in the fields of pedagogy, sociology, ethnopsychology and folklore belongs to the name of Dr. Antin Knyazhynskiy, one of the accomplices of the Ukrainian education, science and culture development in Galicia 20-30 years of the last century, one of the first Ukrainian ethnopsychologists.

Professor Antin Knyazhynskiy is a man of great interest, great work ability and invincible strength of spirit. Having put his life on the altar of service to his native people, he tried to direct all his forces to the development of Ukrainian education, culture and science: a teacher - he was a teacher of Ukrainian, Latin, Polish and German languages and literatures in gymnasiums of Yavorov, Drohobych, Ternopil, Sambir, Kolomyia and Teaching Seminary in Sambir; co-founder of the Society and the Boykivshchyna Museum in Sambir; the author of scientific works on ethnopsychology, sociology, folklore, literary studies; editor, actor, director, ethnographer, writer. In 1945-55 he was a prisoner of concentration camps of the USSR.

The article gives a brief history of life and pedagogical activity of Antin Knyazynskiy. On the basis of the memoirs of his students, the main features of Knyazhynskiy as an outstanding Ukrainian teacher of the 20-30's of the twentieth century were described.

Keywords: Antin Knyazhynskiy; pedagogy; psychology; Sambir gymnasium; "Boykivshchyna".

П остановка проблеми та аналіз основних досліджень та публікацій. В історії західноукраїнської педагогіки початку XX ст. $є$ багато відомих імен. Це імена сподвижників, які докладали чимало зусиль до становлення українського шкільництва в тогочасних суспільно-політичних умовах. Інформація про життя, діяльність та творчість більшості 3 них ховалася у секретні архіви або ж знищувалася. Аж з 90-х років XX ст. українці дістали можливість вільно опрацьовувати збережені матеріали дорадянського періоду та публікувати інформацію про діячів української культури та освіти, про їхні творчі здобугки.

До маловідомих імен в царині педагогіки, соціології, етнопсихології та фольклористики належить ім'я доктора Антіна Княжинського, одного із західноукраїнських педагогів, що дбав не лише про викладання свого предмету, але і доклався до розвитку української освіти і культури в Галичині у $20-30$ х pp. XX ст. Наукових досліджень про Антіна Княжинського на даний час немає. Окремі статті та згадки про його творчість і життя опублікували Б. Стебельський, К. Куб'як, Я. Радевич-Винницький, М. Лесів, М. Андрусяк.

У 1983 році в Канаді у додатку до "Гомону України”, “Література і мистецтво” Богдан Стебельський (український художник, професор філософії, мистецтвознавець, журналіст, член НТШ, колишній учень Самбірської гімназії) до 90річчя від дня народження Антіна Княжинського опублікував аналітичну статтю про його етнопсихологічну працю “Дух нації” [10]. Вона 
була написана ще в 30-х роках XX ст. і була готова до друку на початку березня 1938 р. Публікація іiі планувалася НТШ на 1939 рік. Але почалася більшовицька окупація і тодішній голова НТШ професор Іван Раковський повернув авторові матеріали. А професор Княжинський заховав повернений рукопис: “...замурував я те все в селянській печі близької місцевости. Там і зотліли всі матеріяли й кінцева частина першої праці, де виклав я свій погляд на методу досліду" $[8,4]$. Перебував тоді професор Княжинський у Коломиї, де викладав у гімназії. Аж після повернення із заслання, будучи на емігації у Філадельфії, доктор Княжинський відновив 3 пам'яті цю втрачену книгу- "Дух нації: соціологічно-етнопсихологічна студія”, яка вийшла друком у 1959 році.

Вперше в Україні про Антіна Княжинського була опублікована стаття "Хто ж він - Антін Княжинський?” Костем Куб'яком у газеті “Самбірські вісті” у 1992 році, у якій автор висвітлив відомі на той час факти $з$ життя професора Самбірської гімназії доктора Княжинського. Цей же дослідник його життя i творчості у 1993 році опублікував статтю “Перщий почесний громадянин Самбора" (до 100-ліття 3 дня народження А. Княжинського), у якій вперше появилася публікація тексту почесної грамоти, якою професор Княжинський був нагороджений у 1938 році [9, 2]. Грамота підписана головами п'ятнадцяти українських товариств, що існували на той час в Самборі i зберігається у музеї "Бойківщина” в Самборі.

Про педагогічну діяльність професора Антіна Княжинського наукових статей немає, оскільки для широкої аудиторії його ім'я невідоме. Познайомити наукову громаду з постатю Антіна Княжинського, охарактеризувати педагогічну діяльність Антіна Княжинського - мета статті.

Виклад основного матеріалу. Народився Антін Княжинський у селі Тисовиця 20 лютого 1893 року в родині священика УГКЦ Петра Княжинського. Батько Княжинського вважав, що початкова освіта в селі не буде найкращим вибором, тому вчився його син Антін у Самборі: закінчив початкову чотирикласну школу, а потім - класичну гімназію імені арцикнягині Ельжбєти. Опісля вступив до Львівського університету на філологічний факультет, де навчався на двох відділах - вивчав латинську та українську філології. Захистив дисертацію на ступінь доктора філософії на двох мовах - латинській і українській - обравши темою свого наукового дослідження порівняльний аналіз “Енеїди” Вергілія та “Енеїди” Котляревського. На той час це було новаторством, на яке викладачі університету довго не погоджувалися. Учень професора Княжинського, архітектор і фольклорист, колишній гімназист Орест Горницький (1911 - 2000), що був знайомий також і з братом Антіна Петровича, Юрієм, на відзначенні 100-літнього ювілею від дня народження доктора Княжинського у 1993 році, згадував: “Це мені розказував його рідний брат Юрко. Він трошки старший від мене був, але ми дуже товаришували 3 ним. Отже так: це була велика рідкість, він (А. Княжинський - Д. В.) студіював у Львові філологію українську і філологію латинську - дві філологї. Можна так було студіювати, але диплом робити треба було окремо. А він добився, щоб здавати “допель діплом" - подвійний диплом. Зібралася комісія, в якій були професори з Відня, з Кракова, з Праги, німці, поляки, чехи. Ну і наші абсолютно не годилися на такий подвійний диплом, бо то була новація якась, але потім удалося йому добитися того, переконати. Тема його праці дипломної була “Енеїда" Вергілія - римська література. А української - "Енеїда" Котляревського. Як він це співставив: прочитав абзац з “Енеїди” Вергілія, перетолкував на німецькій мові (бо тоді все ішло на німецькій мові). А потім взяв той самий абзац 3 “Енеїди” Котляревського. І коли появилися між богами римськими і богинями наші козаки зі своїми звичаями, зі своїм гумором, то комісія прямо реготалася, і повставали, поздоровляли його, гратулювали, навіть не дали йому закінчити. "Sehr gut" - дуже добре, здав, значиться, i просили, щоб він цю свою працю прочитав студентам на універзитеті” [2].

У 1920 році А. Княжинський почав викладати українську мову в Самбірській чоловічій гімназії, котру колись закінчив, а з 1921 року і в жіночій учительській семінарії, котра була відкрита в цей рік. Професор Княжинський - співзасновник товариства і музею “Бойківщина” в Самборі у 1927 році (разом з В. Гуркевичем, В. Кобільником, М. Скориком, І. Филипчаком, В. Кордубою та ін.), у 193738 рр. - голова товариства У 1938 році переїжджає у Коломию, де працює спочатку викладачем, а потім - директором гімназії. 31941 року призначений головою Окружного комітету української влади. У 1943 році з наказу УЦК переїздить у Новий Санч, де очолює Окружний комітет. 1944 року переноситься до Відня, де працює у “виконному осередку УЦК”, який опікувався емігрантами з України [6, 7 - 8].

У 1945 році був заарештований НКВД. У 1945 - 55 рр. - в'язень концентраційних таборів СРСР. У 1955 році А. Княжинського було звільнено. Статус громадянина Австрії дав йому змогу повернутися до Відня, звідки він виїхав до 


\section{ПЕДАГОГЧЧНАДІЯЛЬНІСТЬАНТІНА КНЯЖИНСЬКОГО}

Філадельфії, США. Спогади про часи ув'язнення у таборах описані у книзі “На дні СССР”, котра була опублікована у 1959 році у США. Антін Княжинський є автором досліджень про Лесю Українку, Тараса Шевченка; автором низки статей з етнографії, фольклору, педагогіки; праць з етнопсихології.

Доктор медичних наук, професор Юліан Децик (1920 - 1997) висловився про таємницю педагогічного талантусвого вчителя А. Княжинського так: “Він вчив і сам вчився. I в тому тайна його величі, в тому тайна його незвичайних успіхів на ниві педагогіки, виховання молоді. Він прекрасно знав психологію, при чому психологію учнів у віковому значенні. ... До кожного він мав свій ключ. Це він досягнув, очевидно, завдяки тому, що він сам постійно вчився. Він сам постійно поглиблював свої знання" [2].

Уроки Антіна Княжинського, за словами очевидців, завжди були на високому рівні. Він умів застосовувати у класі не лише глибинні, енциклопедичні знання мов і літератур (вільно володів восьма мовами), але і володів знаннями 3 педагогіки та психології. Колишня учениця жіночої вчительської семінарії "Рідної школи" Самбора, що була заснована Теодором Біленьким у 1921 році, Ярослава Турчан на вечорі пам'яті Антіна Княжинського, що відбувся у 1993 році, згадувала: “Доктор Княжинський - це був високоерудований та обдарований викладач. Його уроки - це була поезія упрозі. Вони були приймані ученицями з великою увагою і глибокою пошаною. Форма і зміст уроку були завжди добре продумані. На його уроках ми почули і про Хвильового, і про Кримського, про Чупринку і про Олександра Олеся, про Рильського, про Грушевського, про Єфремова, про Тичину, про Шевченка і Франка, i Лепкого. Але як чудово він пояснював твори Лесі Українки" [2].

А. Княжинський заохочував учнів до читання і української, і зарубіжної художньої літератури. Свої міркування на тему “доповняльної лєктури” (додаткового читання) професор Княжинський виклав у статті “Доповняльна українська лєктура в народній школі”, що була вперше опублікована у часописі "Учительське слово" у 1939 році. Потреба додаткового читання, на думку Княжинського, виправдана "кількома важними вимогами, що їх можна розглядати: а) 3 погляду психіки учня, б) з погляду потреб суспільного середовища, в) з погляду загальних культурних потреб, врешті г) 3 погляду потреб середньої школи" [7, 77].

На основі аналізупоставлених вимог професор Княжинський дає педагогам ряд рекомендацій щодо підбору книжок для додаткового читання, щоби “повести учня далеко поза рідний край, за море, а головно повести його в минуле своє й чуже, не лякаючись давнього Риму, Греції чи інших земель античного світу” [7, 79].

Головною думкою у цій статті Княжинського $€$ “будова душі учня”, що підносило би культурний рівень загалу.

Піднесення культурного рівня народу та його інтелектуального розвитку через книгу Княжинський здійснював і у практичній діяльності. Дбаючи про те, щоб учні читали і українську, і світову літературу в перекладах, професор Княжинський у Самбірській гімназії на громадських засадах створив бібліотеку, якою сам опікувався [2]. Розвиваючи в учнях любов до рідної літератури Княжинський організував у гімназії "Гурток любителів української літератури”, яким керував. У 1932 році бібліотека гуртка налічувала 510 томів. 11 березня того ж року гуртком була організована академія на вшанування Т. Шевченка, після якої відбулося 16 зустрічей гуртка, на яких звучали учнівські доповіді і провадились дискусії $[11,45]$.

У спогадах учнів професора Княжинського знаходимо свідчення про те, яким він був учителем. Колишній учень Коломийської гімназії з українською мовою викладання В. Верига пише: “Він був добрим педагогом: викладав цікаво, але при тому був вимогливий” [1]. Його вимогливість виражена була і в оцінюванні робіт учнів. Порівнюючи своє навчання у Заліщицькій польській гімназії та Коломийській гімназії, Василь Верига доходить висновку, що “моя оцінка "іще достаточно” (задовільно - Д. В.) у Княжинського варта була в мене далеко більше, ніж “дуже добре" в Котовича" [1].

Навчаючи української чи латинської мови чи літератури професор Княжинський вмів зацікавити учнів. Педагог Богдан Грицак так охарактеризував уроки улюбленого вчителя: “Його уроки були настільки цікаві - ми були як заворожені. I що дивне - ніяких жестів, ніякого повишеного тону, все у нього однакова поза, він десь глядів в вікно далеко і нам розказував. А ми бачили в нашій уяві все абсолютно, що він розказував. I коли був дзвоник, ми дуже сприймали ці дзвоники нерадо попросту, ми просили його, щоб він залишився ще після уроків і нам розказував" [3].

Засобами впливу Княжинського на учнів було використання на уроках художнього тексту i застосування акторської майстерності. Учень Княжинського, педагог Добрянський, згадує: “...я хочу підкреслити, те що мені запамяталось, що 
одним із засобів його впливу на учня було саме використовування художнього тексту. Я би не сказав, що це було якесь відкриття, якась новина, звичайно, кожен вчитель використовує текст, це так. Але, разом з тим, настільки вдало, настільки емоційно і настільки діюче на аудиторію читав професор Княжинський, що цього забути ніяк не можу" [2].

Окрім університетської освіти А. Княжинський закінчив драматичну школу, про що згадує учениця семінарії Ярослава Турчан. Княжинський “був знаменитим декламатором, добрим актором і режисером. Десь в 20-х роках ... він виступав як Хома у п’єсі “Ой не ходи, Грицю”, яку сам режисерував. Інсценізував також “Лісову пісню” Лесі Українки, часто режисерував постановки народних п’єс на аматорській сцені у залі української “Бесіди” [2].

Будучи викладачем української мови у відкритій в Самборі вчительській семінарії, Антін Княжинський здійснив з ученицями постановку Франкового “Лиса Микити”. 3 цією виставою навіть була здійснена поїздка до Дрогобича [2]. У тому ж 1929 - 30 навчальному році професор Княжинський організував великий концерт в честь Тараса Шевченка, на якому виступали мішаний хор української семінарії жіночої "Рідної школи”, учнів першої гімназії і мужеского державного семінара [2]. Залучаючи своїх учнів до організації вистав та концертів, А. Княжинський виховував їх у патріотичному дусі, сприяв їх культурному та інтелектуальному розвиткові.

У 1927 роціразом з В. Гуркевичем,В. Кобільником, В. Кордубою, І. Филипчаком доктор Княжинський був співзасновником товариства і музею “Бойківщина”. Як наставник української молоді, професор Княжинський вважав, що повноцінне виховання українського патріота повинне базуватися на знанні свого краю. Тому старався, щоби вихованці гімназії відвідували музей “Бойківщина". Залучав учнів гімназії до участі у фольклорних експедиціях, які організовував. Так звані “прогульки” надовго залишилися у пам'яті багатьох його учнів. Наприклад, Орест Горницький пише: “ОДного разу на паузі (перериві) скликав нас проф. Княжинський і заповів (повідомив - Д. В.): “Хлопці зближаються свята "Wszystkich świętych” тож будемо мати два дні “вільного" отже поїдемо в гори... "на дівчата" сказав з усмішкою, а по хвилині (коли побачив наші здивовані обличчя), додав: - поїдемо робити зарисовку і опис курних хат, які щороку щезають як миляні бульки". ... Безперечно, серед нас, учнів, не було таких, які занимались би научною роботою в цілому того слова значенні ... Радше це була молодеча романтика, яка тягне нас в незнані мандри, а такі прогульки під керівництвом проф. Княжинського завсігди були веселі, цікаві і неповторні” $[5,2]$. Такі “прогульки” окрім запису традицій, пісень, легенд та зарисовок завершувалися зазвичай бесідою професора Княжинського зі своїми вихованцями: “Коли ми вже сиділи у вагоні, повертаючись до Самбора, професор Княжинський аналізував висліди нашої експедиції, зокрема "погляди" на курну хату старого газди: "Не треба осуджувати його погляди на курну хату, бо цей консерватизм, традиція і “зацофаність”, на перший погляд, являються непрогресивними, але вони допомогли зберегти надбання народної культури, звичаїв, обрядів, народних пісень, народного одягу і побуту" $[5,2]$.

Виховував своїх учнів професор Княжинський і на перервах між заняттями. У 20-х роках ХХ ст. в Самбірській гімназії після прикрого випадку травмування учня під час гри у сніжки, дирекція прийняла рішення про заборону цієї гри, для чого організувала чергування вчителів. Чергування полягало в тому, щоби не дозволяти учням кидати сніжки. Антін Княжинський “на свій риск дозволив заборонену гру, але надав їй організаційного порядку. Розробив правила гри, щоб вона стала безпечною і більш культурною" $[4,1]$. Вміння контактувати 3 дітьми та виховувати їх у грі одна 3 рис педагогіки Княжинського. "Пригадую собі (як учасник вказаних “боїв”) з яким нетерпінням ми чекали того дня, коли “дижурити” буде проф. Княжинський, адже ми виладовували свою не лише фізичну енергію - “рух", що притаманне молоді, але i привикали до культурного ведення ігор i пошанування обов'язуючих “законів” [4, 2].

Висновки. Життя та педагогічна діяльність Антіна Петровича Княжинського - одна 3 найяскравіших сторінок західноукраїнської педагогіки початкуминулого століття. А. Княжинський був зразком для своїх учнів, прикладом для наслідування. Емоційний контакт 3 учнями на уроках та по за ними, глибина його знань 3 української, латинської, грецької, німецької мов та літератур, вміння знайти підхід до кожного учня - визначальні професійні риси, що характеризують його педагогічну діяльність.

Обширність знань 3 психології, педагогіки, лінгвістики, етнографії, біології, економіки, філософії, соціології є свідченням постійного самовдосконалення, поглиблення власних знань. Ця риса професора Княжинського спрямовувала його вихованців так, щоб вони могли осягнути якнайбільше, привикнути до того, що не можна в житті обмежуватися чимось одним. 
Доктор Антін Княжинський своєю багатогранною працею вніс великий вклад у розвиток української культури та освіти.

\section{ЛІТЕРАТУРА}

1. Верига В. Один рік в Коломиї [Електронний ресурс] // Коломия, ТРК Рідні медія [веб-сайт] / / Режим доступу: http://kolomyya.org/histpub/ historypub71.htm

2. Відеозапис відзначення 100-літнього ювілею А. Княжинського в Самборі. 1993. - родинний архів Д. Василик.

3. Відеозапис відзначення 100-літнього ювілею А. Княжинського в с. Тисовиця, 1993. - родинний архів Д. Василик.

4. Горницький О. Гра в сніжки // Рукопис 3 родинного архіву Д. Василик, 1999. - 2 с.

5. Горницький О. Спомин минулих літ: Про курну хату в селі Вовче // Рукопис з родинного архіву Д. Василик, 1999. - 2 с.

6. Княжинський А. Дещо про себе // На дні СССР. - Нью Йорк: ООЧСУ, 1959. - С. 5-8.

7. Княжинський А. Доповняльна українська лектура у народній школі // Учительське Слово. - 1939. - Ч. 11. - С. 77-80.

8. Княжинський А. Переднє слово // Дух нації: соціологічно-етнопсихологічна студія. - Нью Йорк - Філадельфія - Мюнхен: Наукове Товариство ім. Т. Шевченка в ЗДА, 1959. - С. 3-7.

9. Куб'як К. Перший почесний громадянин Самбора // Самбірські вісті. - Ч. 21 (368). - 20 лютого 1993. - с. 2.

10. Стебельський Б. Антін Княжинський (у 90річчя від дня народження найвизначнішого українського етнопсихолога) // Література i мистецтво. - №9(416). - 1983 - - Торонто, Канада. - C. 1-2.

11. Sprawozdanie Dyrekcji I. Pacstwowego Gimnazjum Mкskiego typu dawnego klasycznego im. Adama Mickiewicza w Samborze za rok szkolny 1931/32. $-86 \mathrm{~s}$.

\section{REFERENCES}

1. Veryha, V. Odyn rik v Kolomyi [One year in Kolomyia] [Electronic resource]. Kolomyia, TRK Native media [web site]. Access mode: http:// kolomyya.org/histpub/historypub71.htm [in Ukrainian].
2. Videozapys vidznachennia 100-litnoho yuvileiu A. Kniazhynskoho v Sambori (1993). [Video recording of the 100th anniversary ofA. Knyazhinsky in Sambir]. The family archive D. Vasylyk. [in Ukrainian].

3. Videozapys vidznachennia 100-litnoho yuvileiu A. Kniazhynskoho v s. Tysovytsia (1993). [Video recording of the 100th anniversary of A. Knyazhinsky in the village of Tysovice]. The family archive D. Vasylyk. [in Ukrainian].

4. Hornytskyi, O. (1999). Hra v snizhky [A game of snowballs]. Manuscript from the family archive D. Vasylyk, 2 p. [in Ukrainian].

5. Hornytskyi, O. (1999). Spomyn mynulykh lit: Pro kurnu hatu v seli Vovche [The reminder of past years: About the dusty hut in the village of Vovche]. Manuscript from the family archive D. Vasylyk, 2 p. [in Ukrainian].

6. Kniazhynskyi, A. (1959). Deshcho pro sebe [Something about myself]. At the bottom of the USSR. New York: Organization for the Defense of Four Freedoms for Ukraine, pp. 5-8. [in Ukrainian].

7. Kniazhynskyi, A. (1939). Dopovnialna ukrainska lektura u narodnii shkoli [Complementary Ukrainian lectureures at the folk school]. Teacher's word. Part 11, pp. 77-80. [in Ukrainian].

8. Kniazhynskyi, A. (1959). Perednie slovo [The Foreword]. The Spirit of the Nation: SociologicalEthnopsychological Studio. New York Philadelphia - Munich: The Scientific Society of them. T. Shevchenko in the State Duma, pp. 3-7. [in Ukrainian].

9. Kubiak Kost. Pershyi pochesnyi hromadianyn Sambora [The first honorary citizen of Sambor]. Sambir news from February 20, 1993, p. 2. [in Ukrainian].

10. Stebelskyi, B. (1983). Antin Kniazhynskyi (u 90-richchia vid dnia narodzhennia naivyznachnishoho ukrainskoho etnopsykholoha) [Antin Knyazhinsky (on the 90th anniversary of the birth of the most prominent Ukrainian ethnopsychologist)]. Literature and art. No. 9 (416). Toronto, Canada. pp. 1-2. [in Ukrainian].

11. Sprawozdanie Dyrekcji I. Pacstwowego Gimnazjum Mкskiego typu dawnego klasycznego im. Adama Mickiewicza w Samborze za rok szkolny 1931/32 [Report of the Directorate of the I. State Gymnasium Male type of the former classical them. Adama Mickiewicza in Sambor for the school year 1931/32] 86 p. [in Polish].

Стаття надійшла до редакції 02.11.2018

\section{G5808012658080

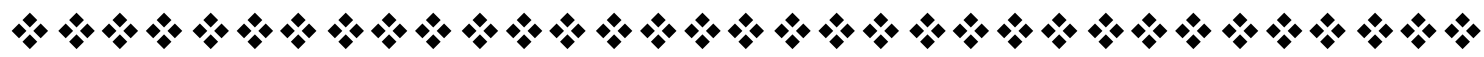

